\title{
STRUKTURASI KEKUASAAN DAN KEKERASAN SIMBOLIK DALAM NOVEL TEMPURUNG KARYA OKA RUSMINI (PERPSEKTIF PIERRE BOURDIEU)
}

\section{Info Artikel \\ Sejarah Artikel: \\ Diterima Februari 2021 \\ Disetujui Maret 2021 \\ Dipublikasikan Mei 2021}

\author{
Khadija R. Ahmad ${ }^{1}$, Ellyana Hinta ${ }^{2}$, Jafar Lantowa ${ }^{3}$
}

\begin{abstract}
This research was conducted to describe power structuration and symbolic violence within Tempurung, a novelby Oka Rusmini. Power structuration and symbolic violence become the focus of this research. This study employedPierre Bourdieu'sperspective to identifythe power structuration and symbolic violence, which was treated as the research data, usinga descriptive method. The data sources were quotes, sentences, and paragraphs in the novel, collectedby referencing, reading, and note-taking. The data were analyzed laterbyusingidentification, classification, analysis, description, and conclusion of data analysis results.

Based on the findings and discussion, it wasrevealed that the novel containedpower structuration, proven by the following findings (1) there are four capitals in the novel, namely economic, social, cultural, and symboliccapitals, and the most influential of these was the social capital. (2) Social classes in the novel are influenced by the capital they own. Agents with the largest capital and habitus that favors these agentsoccupied the dominant position.Thesmall bourgeoisie classes, on the other hand, are occupied by agents with ambitions to climb the social ladder; this class possessesmorecapital than the popular class but they are still a recipient of symbolic violence. The popular class contains agents with the least capital, which leads to it being the most often recipient of the symbolic violence. (3) The habitus involvedin the novel is a social habitus in Balinese society. (4) The realm involvedin the novel is a realm of social community in Bali.Furthermore, the symbolic violence in the novelemploys euphemisms and sensorymechanism, while most ofthe symbolic violence are committed by agents who possess the social capital such as parents to their children and other social relationships.
\end{abstract}

Keywords:PowerStructuration, Symbolic Violence, Novel, Bourdieu

\footnotetext{
Alamat Korespondensi:

Jurusan Bahasa dan Sastra Indonesia, Fakultas Sastra dan Budaya, Universitas Negeri Gorontalo

Email: khadijarahmad21@gmail.com; ellyanahinta@ung.ac.id; jafar.lantowa@ung.ac.id
} 


\section{ABSTRAK}

Penelitian ini dilakukan dengan tujuan untuk mendeskripsikan strukturasi kekuasaan dan kekerasan simbolik yang terjadi dalam novel Tempurung karya Oka Rusmini. Fokus penelitian yaitu 1) strukturasi kekuasaan; dan 2) kekerasan simbolik dalam novel Tempurung karya Oka Rusmini.

Penelitian ini menggunakan perspektif Pierre Bourdieu untuk menemukan strukturasi kekuasaan dan kekerasan simbolik. Metode penelitian ini adalah metode deskriptif. Data penelitian yakni strukturasi kekuasaan dan kekerasan simbolik. Sumber data adalah kutipan, kalimat dan paragraf yang terdapat dalam novel Tempurung karya Oka Rusmini. Teknik pengumpulan data yaitu teknik pustaka, baca dan catat. Teknik analisis data dilakukan dengan cara mengidentifikasi, mengklasifikasi, menganalisis, mendeskripsikan dan menyimpulkan hasil analisis data.

Berdasarkan hasil penelitian dan pembahasan dapat disimpulkan bahwa pertama terdapat strukturasi kekuasaan dalam novel Tempurung karya Oka Rusmini yakni (1) adanya keempat modal di dalam novel tersebut yakni modal ekonomi, modal sosial, modal budaya dan simbolik. Namun, modal yang paling berpengaruh yakni modal sosial. (2) kelas-kelas di dalam novel Tempurung karya Oka Rusmini di pengaruhi oleh modal yang mereka miliki. Agen yang memiliki modal yang paling banyak dan habitus yang berpihak kepada mereka menduduki kelas dominan, sementara kelas bourjuis kecil diduduki oleh para agen yang memiliki ambisi untuk menaiki tangga sosial, kelas ini memiliki modal yang lebih banyak dari kelas popular, namun bukan berarti mereka tidak menerima kekerasan simbolik. Selanjutnya, kelas popular berisikan agen yang memiliki modal paling sedikit, sehingga paling sering mendapatkan kekerasan simbolik. (3) habitus dalam novel Tempurung karya Oka Rusmini merupakan habitus sosial yang terdapat dalam masyarakat Bali. (4) ranah yang terdapat dalam novel Tempurung karya Oka Rusmini yakni ranah sosial masyarakat Bali. Kedua kekerasan simbolik dalam Novel Tempurung karya Oka Rusmini menggunakan mekanisme eufemisme dan sensorik. Kekerasan simbolik yang paling banyak terjadi yakni kekerasan simbolik yang dilakukan oleh para agen pemilik modal sosial seperti orang tua terhadap anaknya dan hubungan sosial lainnya.

Kata kunci: strukturasi kekuasaan, kekerasan simbolik, novel, Bourdieu 


\section{PENDAHULUAN}

Sastra adalah sebuah bentuk imajinasi dan kreativitas yang menggunakan manusia dan kehidupannya sebagai objek dan disusun dengan bahasa yang indah. Hal ini sejalan dengan yang dikatakan Tuloli (dalam Didipu, 2012:3) bahwa sastra merupakan hasil kreativitas pengarang yang bersumber dari kehidupan manusia secara langsung atau melalui rekaanya dengan bahasa sebagai mediumnya. Sementara, menurut Taum sastra adalah karya cipta atau fiksi yang bersifat imajinatif atau sastra adalah penggunaan bahasa yang indah dan berguna yang menandakan hal-hal lain (Surastina, 2018: 4).

Karya sastra merupakan salah satu objek penelitian yang selalu menarik untuk diteliti. Hal ini dikarenakan realitas yang terdapat di dalam karya sastra. Realitas tersebut disusun dengan sangat apik oleh penulisnya, sehingga karya sastra tidak hanya untuk dinikmati. Namun, makna berlapis yang terdapat di dalamnya merupakan sebuah tantangan tersendiri untuk diteliti. Novel adalah salah satu bentuk karya sastra yang mengambarkan atau menceritakan permasalahan kehidupan yang kompleks. Menurut Aziez dan Hasim (dalam Didipu,2012: 44) novel merupakan genre sastra yang memiliki bentuk utama prosa, dengan panjang yang kurang lebih bisa untuk mengisi satu dan dua volume kecil, yang menggambarkan kehidupan nyata dalam suatu plot yang cukup kompleks. Permasalahan kehidupan yang kompleks digambarkan dengan bahasa yang apik dan menarik, sehingga membawa pembaca ikut larut dalam cerita yang digambarkan. Masalah kehidupan yang digambarkan pun tidak akan jauh-jauh dari pola kehidupan masyarakat.

Dalam kehidupan bermasyarakat, akan ada pihak yang mendominasi dan terdominasi. Pihak yang mendominasi adalah pihak yang mempunyai modal paling baik sehingga pihak ini dapat dengan mudah menguasi pihak terdominasi atau pihak yang mempunyai modal paling buruk. Hal ini akan menciptakan sebuah relasi kekuasaan antara pihak yang mendominasi dan pihak yang terdominasi. Bahkan tidak jarang relasi kekuasaan dapat mengakibatkan terjadinya kekerasan.

Kekerasan merupakan segala bentuk perilaku yang memiliki tujuan untuk menyakiti seseorang, baik secara fisik maupun mental. Kekerasan merupakan pangkal dari hasil 
kekuasaan, sehingga erat hubungan antara kekuasaan dengan kekerasan. Kekerasan dapat dilakukan secara fisik maupun verbal. Kekerasan fisik adalah kekerasan yang melibatkan kontak langsung dan dimaksudkan untuk menimbulkan perasaan intimidasi, cedera, atau penderitaan fisik atau kerusakan tubuh. Kekerasan verbal adalah segala bentuk ucapan yang bertujuan untuk menghina, membentak, memaki, memarahi, dan menakuti dengan mengeluarkan ucapan, yang tidak pantas kepada seseorang. Namun, kadangkala kekerasan yang terjadi dalam masyarakat merupakan kekerasan yang tidak dirasakan sebagai sebuah kekerasan oleh pihak yang didominasi. Hal ini disebabkan karena pihak yang mendominasi merasa hal tersebut merupakan hal yang biasa saja. Bourdieu menyebut kekerasan tersebut sebagai kekerasan simbolik.

Kekerasan simbolik adalah kekerasan yang bentuknya sangat halus, kekerasan yang digunakan pada agen-agen sosial tanpa mengundang resistensi, sebaliknya malah akan mengundang persetujuan sebab telah medapatkan dukungan ataupun telah dianggap sebagai sesuatu yang sah oleh suatu masyarakat tertentu karena bentuknya sangat halus (Bourdieu dalam Harker, 2009: xxi). Oleh sebab itu, kekerasan simbolik sangat menarik untuk diteliti karena kebanyakan masyarakat tidak menyadari bahwa mereka sedang mengalami kekerasan simbolik.

Kekerasan ini terjadi karena adanya elemen-elemen pembentuk kekuasaan yang dimiliki oleh seseorang, dari kekuasaan inilah seseorang dapat melakukan kekerasan terhadap orang lain. Elemen pembentuk kekuasaan ini disebut sebagai strukturasi kekuasaan. Adapun strukturasi kekuasaan tersebut yakni arena, habitus, modal dan kelas. Habitus adalah alat pemersatu pikiran dan tindakan setiap orang yang terdapat dalam satu ranah. Ranah adalah ruang terstruktur yang menciptakan relasi antara berbagai posisi atau kelas, tempat berlangsungnya pertarungan antara kelas. Modal adalah sebuah kekuataan untuk dapat bertarung dalam sebuah ranah.

Salah satu novel yang mengambarkan permasalahan tersebut adalah novel Tempurung Karya Oka Rusmini. Novel ini menceritakan tentang kehidupan perempuan yang dihadapkan dengan persoalan tubuh, agama, budaya dan masyarakat. Novel ini 
mengambarkan segala permasalahan wanita Bali yang dalam hal ini merupakan sebuah bentuk kekerasan yang dianggap sebagai sesuatu yang sudah sewajarnya atau dapat dikatakan pihak yang didominasi tidak merasakan bahwa yang dilakukan kepadanya merupakan satu tindak dari kekerasan. Kebanyakan sosok wanita yang digambarkan dalam novel ini tidak merasa keberatan dengan perbuatan seseorang kepadanya. Kekerasan yang terjadi dalam novel ini tidak hanya dilakukan antara kaum pria kepada wanita, namun juga wanita ke wanita lainya. Karena permasalahan yang kompleks tersebut, peneliti tertarik untuk meneliti Strukturasi kekuasaan dan kekerasan simbolik yang terdapat dalam novel Tempurung karya Oka Rusmini.

Penelitian ini akan menggunakan perspektif Pierre Bourdieu, hal ini disebabkan pemikiran bourdieu sejalan dengan permasalahan sosial yang terjadi dalam novel Tempurung karya Oka Rusmini yakni strukturasi kekuasaan dan kekerasan simbolik. Menurut Krisdinanto (2014:107-206), Bourdie mengasumsikan bahwa dominasi selalu ada dalam masyarakat. Oleh karena itu, dalam kehidupan masyarakat akan ada pihak yang mendominasi dan terdominasi. Pierre Felix Bourdieu merupakan salah seorang filsuf yang bidang kajiannya meliputi sastra, bahasa, sosiologi, psikologi, politik, dan bahkan ekonomi. Teoriteori yang ditemukan olehnya dapat digunakan dalam meneliti segala aspek baik sastra, bahasa, sosial, psikologi, politik bahkan ekonomi sekali pun.

\section{Metode Penelitian}

Pendekatan penelitian yakni menggunakan pendekatan kualitatif. Menurut Denzin (dalam Moleong, 2014: 5) penelitian kualitatif adalah penelitian yang menggunakan latar alamiah, dengan maksud menafsirkan fenomena yang terjadi dan dilakukan dengan jalan melibatkan berbagai metode yang ada. Jenis penelitian ini menggunakan jenis penelitian deskriptif. Penelitian deskriptif adalah penelitian yang digunakan untuk menggambarkan dan menginterpretasi permasalahan yang terdapat dalam sebuah objek yakni novel. Hal ini sesuai dengan pendapat Arifin (2010:113) bahwa metode deskriptif digunakan untuk memerikan, menggambarkan, menguraikan dan menjelaskan data atau objek secara alami, objektif, dan 
apa adanya (faktual).

Teknik pengumpulan data yang digunakan dalam penelitian ini adalah teknik pustaka, simak dan catat. Menurut Subroto (dalam Imron, 2003: 356) teknik pustaka adalah teknik yang menggunakan sumber-sumber tertulis untuk memperoleh data, sedangkan teknik simak dan catat berarti peneliti sebagai instrumen kunci melakukan penyimakan secara cermat, terarah, dan teliti terhadap sumber data primer. Teknik analisis adalah teknik yang digunakan dalam menginterpertasi data-data yang menjadi objek penelitian.

\section{HASIL PENELITIAN}

Bagian ini akan mendeskripsikan strukturasi kekuasaan dan kekerasan simbolik dalam novel Tempurung karya Oka Rusmini.

\section{STRUKTURASI KEKUASAAN}

\section{Modal}

Terdapat empat jenis modal yang terdapat dalam sebuah ranah yakni modal ekonomi, modal budaya, modal sosial dan modal simbolik. Berikut data yang menunjukan modal dalam novel Tempurung karya Oka Rusmini.

a. Modal Ekonomi

... Glatik tidak setuju. Dia menyuruhku tinggal di rumahnya. Sebuah rumah munggil yang tertata sangat rapi, taman yang luas, juga ratusan anggrek di kebun belakang. Aku tidak menyangka perempuan itu begitu kaya. Luas tanahnya 1000meter persegi. Ternyata dia penjual bunga potong. Luar v biasa! Bisnisnya sudah merambah hotel-hotel bintang lima di Nusa Dua. Pegawainya mulai dari tukang potong bunga, antarbunga, sampai sopir, semua perempuan! (Rusmini, 2018:48).

Seperti yang telah dijelaskan sebelumnya, bahwa modal ekonomi tidak hanya menyangkut persoalan uang. Namun juga benda dan alat produksi. Tokoh Glatik memiliki hal tersebut. Hal ini tampak dari data di atas. Ia memiliki sebuah rumah dengan luas tanah 
1000 meter. Selain itu, dia juga memiliki alat produksi seperti sebuah kebun anggrek yang hasil anggrek atau bunga potongnya telah merambah hotel-hotel berbintang. Hasil dari penjualan bunga potong tersebut dapat menambah pendapatan dari tokoh Glatik. Dengan demikian, modal yang dimilikinya sesuai dengan data diatas digolongkan sebagai modal ekonomi. Dengan modal tersebut, ia mendapatkan peluang untuk dapat mendominasi seseorang yang memiliki modal lebih sedikit dari modal yang dimilikinya.

b. Modal Budaya

"Ini semua gara-gara KB! Kata dokter spesialis kulit, bekas teman tiang (dia selalu menyebut dirinya, tiang,artinya saya), semua ini pengaruh pil yang tiang pakai puluhan tahun. Namanya perempuan, kalau tidak pakai KB, ratusan anak bisa lahir. Yang repot siapa? Perempuan juga. Konon kalau pakai IUD lebih aman. Tapi tiang takut. Masa ada benda yang terbuat dari plastik dan tembaga berbentuk $T$ dimasukan ke dalam rahim? Pemakaiannya bisa 4-5 tahun. Dayu tahu ketika alat itu dipasang, kita harus menaikan kaki tinggi-tinggi. Mengangkang! Yang buat tiang ngeri, kita harus memeriksa diri sendiri apakah alat kontrasepsi itu masih ada dalam rahim dengan cara meraba benang IUD tersebut di dalam vagina. Waduh, takut tiang memasukan jari sendiri ke ..." (Rusmini, 2018:8).

Pengetahuan yang dimiliki Ibu Barla tentang keadaan tubuhnya tergolong modal budaya. Meskipun pengetahuan tersebut didapatkannya melalui dokter spesialis kulit yang merupakan bekas temannya. Namun, tanpa pengetahuan dasar yang dimilikinya hal tersebut tidak akan membekas dan tertanam dalam pikirannya. Pengetahuan tersebut didapatkan melalui proses pembelajaran yang ia lakukan. Hal ini dibuktikan dengan pengetahuannya tentang alat kontrasepsi yang bisa bertahan hingga 4 sampai 5 tahun, serta pengetahuannya tentang cara pemasangan alat kontrasepsi tersebut. 
c. Modal Sosial

Mejer, konon abdi yang sangat disayang oleh Raja Denpasar. Dia Rajin merawat kuda milik raja. Kata orangorang, Mejer bisa bicara dengan kuda. Kuda raja pun jadi sakti, dan bisa hidup puluhan tahun tanpa pernah sakit. Pengabdiannya yang tulus itu membuat raja menghibahkan tanah padanya... (Rusmini, 2018:11).

Hubungan yang terjalin oleh Raja Denpasar dan Mejer terbentuk karena adanya hubungan timbal balik antara Raja Denpasar dengan Mejer. Walau bukan anggota keluarganya, Raja sangat menyayangi Mejer. Mejer merupakan seorang abdi yang bertugas untuk merawat kuda milik Raja Denpasar. Atas ketulusan hatinya menjaga kuda milik raja, rajapun menghibahkan tanah padanya. Secara tidak langsung, hal ini membentuk hubungan sosial antara keduannya. Atas modal sosial yang dimilikinya tersebut, dia pun mendapatkan sebuah modal lainnya yang dapat membantunya untuk dapat bertahan dalam ranah tersebut.

d. Modal Simbolik

Glatik itu sangat cantik. Menurut teman-temanku dari Jawa, wajahnya sangat berkarakter. Kata mereka, tampangnya sangat klasik. Kelihatan sekali karakter perempuan Bali masa lalu. Rambutnya lurus, bola mata besar, jari-jari tangan panjang dan lentik, tubuh kurus. Proposi seorang penari. Memang glatik seorang penari. Tepatnya, dosen tari. Menurutku, dia cantik sekali, sekalipun kulitnya hitam. (Rusmini, 2018:49)

Modal simbolik yang dimiliki Glatik berupa status sosial. Profesinya sebagai dosen tari termasuk dalam jenis modal simbolik. Dengan modal yang dimilikinya, dia dapat melakukan tindakan atau hak untuk memerintah orang lain. Hak yang dimilikinya berkaitan dengan profesinya sebagai dosen, hak untuk memerintah dan memutuskan nilai yang tepat untuk mahasiswanya. Dengan otoritas yang didapatkan, dia dapat berkuasa dalam ranah tersebut. Meskipun, hal tersebut tidak menjamin bahwa dia akan menang dalam sebuah ranah. 


\section{Kelas}

Bourideu membedakan kelas menjadi tiga, yakni kelas dominan, kelas borjuis kecil dan kelas popular. Kelas dalam novel Tempurung karya Oka Rusmini dikelompokan berdasarkan habitus dan akumulasi modal yang dimiliki. Kelas dominan ditempati oleh para orang tua, Glatik, Raja Denpasar, dan Ida Ayu Made Pidagda, Masyarakat juga menjadi kelas dominan dalam novel ini. Kelas bourjuis kecil ditempati oleh tokoh Barla dan Mejer. Sementara untuk kelas popular ditempati oleh tokoh Ni Luh Putu Saring, Sipleg, Songi, Arsiki, Rosa, Regina dan masyarakat. Masyarakat dapat menjadi kelas dominasi dan kelas popular sesuai dengan situasi, habitus dan modal yang mereka miliki.

\section{Habitus}

Habitus merupakan sebuah alat pemersatu pemikiran serta tindakan suatu kelompok yang berada dalam sebuah ranah tertentu. Oleh karena itu, dalam penelitian ini habitus akan dideskripsikan berdasarkan kelas.

\section{a. Habitus Kelas Dominan}

Habitus yang dimiliki oleh kelas dominan dalam novel Tempurung karya Oka Rusmini yakni mereka dapat melakukan hal apapun kepada orang yang memiliki modal lebih sedikit. Terlebih lagi pemilik tokoh yang memiliki modal sosial. Hubungan yang mereka miliki dengan kelas populer membuat mereka dapat kekerasan simbolik kepada kelas populer. Misalnya, sebagai orang tua, mereka berhak untuk mendominasi anak-anaknya. Setiap langkah yang mereka pilih, harus diikuti oleh anak-anaknya. Hal tersebut akan dinilai sebagai hal yang wajar karena habitus yang mereka miliki. Orang tua mengetahui apa yang terbaik untuk anaknya. Anak yang tidak mematuhi perkataan orang tuanya akan dianggap sebagai anak pembangkang bahwa dicap sebagai anak durhaka. Dengan habitus tersebut, para orang tua dapat dengan bebas melakukan dominasi kepada anak-anaknya.

Dulu, ketika aku masih tinggal di desa, nama itu tak menggangguku. Setelah pindah ke Denpasar, aku malu dengan nama itu. Seorang teman di sekolah bahkan pernah 
menggodaku. "Pantas ibumu memberimu nama Saring, habis rambut keritingmu seperti saringan" aku hanya diam. Dan tidak pernah berusaha mengganti namaku. (Rusmini, 2018:25)

Dari data di atas dapat kita lihat bahwa orang tua dapat melakukan apapun kepada anaknya. Setiap orang tua berhak untuk mengatur anaknya sesuai dengan keinginan mereka. Oleh karena itu, dalam novel Tempurung karya Oka Rusmini orang tua digolongkan sebagai kelas dominan. Mereka secara bebas dapat melakukan dominasi kepada anaknya. Mereka tidak memikirkan hal apa yang akan terjadi kepada anaknya dan hanya melakukan apa yang menurut mereka baik, seperti yang dilakukan oleh orang tua Saring. Nama yang mereka berikan kepada anaknya hanya sesuai dengan keinginan mereka. Mereka tidak memikirkan perasaan anaknya di masa yang akan datang. Sementara anaknya hanya bisa menerima apapun yang diputuskan oleh orang tuanya.

Pemikiran para orang tua dengan memutuskan apapun tentang kehidupan anaknya, menjadikan hal tersebut sebagai habitus. Hal ini tidak hanya terjadi dalam hal pemberian nama, namun pada hal apapun yang berkaitan dengan kehidupan anaknya, termaksud pendidikan.

\section{b. Habitus Kelas Bourjuis Kecil}

Kelas bourjuis kecil ditandai dengan keinginan untuk menaiki tangga sosial. Meskipun menduduki tingkat menengah dalam status sosial dalam struktur masyarakat namun ambisi kaum bourjuis untuk lebih meningkatkan status sosial mereka sangatlah besar. Hal ini tampak pada tokoh wanita yang menjadi SPG senior dalam novel Tempurung karya Oka Rusmini. Wanita ini telah banyak mengalami pahit manisnya kehidupan. Oleh karena pengalamannya tersebut, membentuk ambisi dalam dirinya untuk menjadi orang yang memiliki modal ekonomi yang lebih baik sehingga dia tidak akan mudah untuk mendapatkan kekerasan simbolik dari orang lain. Ambisi tersebut berubah menjadi habitus yang mengatur pola pikirnya untuk melakukan hal untuk merubah status sosialnya. Berikut data yang memperlihatkan habitus yang dimiliki oleh SPG senior tersebut. 
Aku menjual diriku. Hubunganku sudah lima tahun. Aku punya rumah besar, mobil. Saat ini aku sedang mengumpulkan uang untuk membeli rumah lagi. Mungkin akan kusewakan untuk modal hari tua. Kecantikanku umurnya tidak mungkin panjang. Hidupku tidak sehat. Aku bukan hanya jadi simpanan lelaki itu. Beberapa pejabat dan orang kaya juga sering mencicipi tubuhku. Apa gosip itu sampai ke telingamu?" (Rusmini,2018:191).

Perempuan tersebut rela menjual dirinya untuk memiliki semua kekayaan yang dimilikinya saat ini. Meskipun dia belum menduduki kelas atas, namun ambisinya untuk memperbaiki perekonomiannya sangatlah besar. Hal ini dilakukannya untuk membuat hari tuanya lebih bahagia. Pengalaman masa muda yang dimiliki perempuan yang bekerja sebagai SPG itu sangatlah kelam. Kisah cintanya di masa muda membuatnya menjadi pribadi yang tidak ingin memiliki hubungan yang serius dengan satu orang pria saja. Menurutnya, dengan menjadi wanita yang memiliki segalanya dia tidak akan memerlukan laki-laki lagi. Perempuan tersebut tidak akan tergantung pada laki-laki tersebut. Habitus tersebut membuat menjadi pribadi kuat dan tidak peduli dengan percintaannya. Ambisinya untuk menaiki tangga sosial lebih kuat dibandingkan dengan persoalan cinta yang telah banyak membuatnya luka di masa lalu. Habitus untuk menaiki tangga sosial ini dimiliki oleh semua kaum bourjuis kecil, meskipun dengan cara dan alasan yang berbeda-beda. Namun, hal tersebut merujuk pada satu tujuan yakni untuk dapat meningkatkan kelas mereka dalam struktur masyarakat.

\section{c. Habitus Kelas Populer}

Habitus kelas populer yakni kepatuhan mereka terhadap orang-orang yang memiliki hubungan dengan mereka, baik hubungan keluarga maupun pertemanan. Kepatuhannya tersebut membuat mereka dengan mudah mendapatkan kekerasan simbolik dari kelas dominan. Misalnya, kepatuhan yang dimiliki oleh Saring terhadap orang tuanya.

Selain itu, sikap kepatuhan tersebut tidak hanya dihadapkan dalam hubungan yang dimiliki. Namun juga, kepatuhan terhadap adat istiadat yang terdapat dalam ranah tersebut. 
Terlebih lagi, ranah dalam novel Tempurung karya Oka Rusmini merupakan ranah sosial yang kental dengan adat istiadatnya. Setiap masyarakat harus patuh dengan aturan-aturan yang terdapat di dalamnya. Hal ini tampak dalam data berikut.

Hyang Jagat! Sipleg melahirkan kembar buncing, kembar lelaki dan perempuan. Ini berarti malapetaka, leteh, kotor bagi desanya. Sebuah upacara besar harus digelar. (Rusmini, 2018:136).

Menurut kepercayaan masyarakat Bali yang tergambar dalam novel Tempurung karya Oka Rusmini, melahirkan kembar buncing merupakan sebuah malapetaka. Seakanakan sebuah bencana akan datang pada desa tempat tinggal pasangan yang melahirkan anak kembar buncing. Oleh sebab itu, upacara untuk membersihkan malapetaka tersebut haruslah diadakan agar seluruh desa akan terlindungi dari malapetaka yang akan terjadi. Upacara yang dapat membebaskan mereka dari sebuah bencana tersebut yakni upacara mecaru manca. Upacara mecaru manca adalah upacara untuk membersihkan diri ke segala penjuru mata angin.

Pemikiran serta tindakan yang harus dilakukan oleh tokoh Sipleg dan suaminya merupakan habitus yang terdapat dalam masyarakat Bali. Habitus yang memperantai pola pikir masyarakat bali yang terdapat dalam novel Tempurung karya Oka Rusmini untuk melakukan upacara mecaru manca ketika melahirkan anak yang kembar buncing. Hal ini membuktikan bahwa habitus berpengaruh dalam mengatur pemikiran serta tindakan sekelompok yang memiliki habitus yang sama.

\section{Ranah}

Ranah yang terdapat dalam novel Tempurung karya Oka Rusmini tersebut, dapat dikategorikan sebagai ranah yang besar yakni ranah sosial. Dikategorikan sebagai ranah sosial karena dominasi yang terjadi dalam novel Tempurung karya Oka Rusmini terjadi dalam ruang kehidupan sosial masyarakat Bali. Kehidupan masyarakat bali yang kental akan tradisi dan budaya yang diturunkan oleh leluhur mereka sangat ditonjolkan dalam novel 
tersebut, termaksud sistem kasta.

Terdapat berbagai macam tingkatan kasta dalam masyarakat Bali, kasta yang tertinggi yakni kasta Ida Ayu/Ida Bagus. Orang yang memiliki kasta ini merupakan seorang bangsawan. Seorang bangsawan harus patuh akan adat istiadat seorang bangsawan Bali. Sementara, kelompok orang yang memiliki kasta lebih rendah dari kasta bangsawan jugas harus menghormati serta mengikuti aturan-aturan yang ada di dalamnya, misalnya masyarakat biasa harus memanggil ratu atau ida ayu kepada perempuan bali yang berkasta Brahmana. Panggilan ratu pada sesorang wanita, menandakan bahwa wanita tersebut memiliki kasta yang lebih tinggi dari orang yang memanggilnya. Hal ini dapat dilihat dalam data berikut.

"Siang malam tiang bekerja, Atu."

(Perempuan itu kadang senang memanggilkuatu atau singkatan dari ratu. Panggilan kehormatan untuk perempuan Bali berkasta Brahmana... (Rusmini,2018:16).

Masyarakat Bali merupakan masyarakat yang hampir keseluruhan masyarakatnya pemeluk agama Hindu. Oleh karena itu, dalam masyarakat Bali terdapat sistem kasta. Namun, sistem kasta dalam masyarakat Hindu Bali memiliki sistem kasta yang lebih sederhana dari pada sistem kasta masyarakat Hindu di India. Brahmana merupakan kasta tertinggi dalam sistem kasta masyarakat Bali. Seseorang yang memiliki kasta Brahmana akan diberi gelar dengan gelar Ida Ayu untuk perempuan dan Ida Bagus untuk laki-laki. Karena itulah, kasta lainya harus memanggilkan orang yang berkasta brahmana dengan sebutan Ratu atau Ida Ayu.

\section{KEKERASAN SIMBOLIK}

Setelah mendapatkan data yang berkaitan dengan elemen pembentuk strukturasi kekuasaan yakni habitus, ranah, dan modal. Selanjutnya, peneliti akan mendeskripsikan data yang berkaitan dengan kekerasan simbolik. Kekerasan simbolik merupakan kekerasan yang dilakukan oleh agen yang memiliki modal paling banyak terhadap agen yang memiliki modal 
paling sedikit, namun kekerasan ini bentuknya sangat halus sehingga tidak akan mendapatkan penolakan dari pihak yang terdominasi, karena merasa hal tersebut adalah hal yang sah-sah saja untuk dilakukan. Berikut kekerasan simbolik yang dilakukan oleh agenagen yang memiliki modal yang banyak dalam novel Tempurung karya Oka Rusmini.

Raja juga menyuruh Mejer memilih salah satu abdi perempuan kerajaan untuk disunting jadi istri. Mejer memilih Ni Ketut Regina, perempuan paling cantik diantara abdi perempuan kerajaan. Pilihan Mejer pada Regina ternyata membuat seorang patih kerajaan merasa dilangkahi. Karena sejak Regina datang ke Puri, sang patih telah terpikat pada perempuan asal dusun karangasem itu. Regina ternyata juga tertarik pada sang patih. Namun, karena keputusan Raja adalah undang-undang, Regina dan Mejer pun dinikahkan. (Rusmini,2018:11)

Kekerasan simbolik yang dilakukan oleh Raja Denpasar terhadap Regina merupakan bentuk kekerasan simbolik berupa perintah. Sebagai seorang abdi kerajaan, Regina haruslah menuruti segala bentuk keputusan Rajanya. Meskipun harus mengorbankan hubungannya dengan Pati kerajaan. Regina tidak merasa bahwa dirinya sedang mendapatkan tindak kekerasan dari Raja Denpasar. Hal ini karena habitus rakyat Denpasar menganggap hal tersebut adalah hal yang sah-sah saja. Segala keputusan Raja merupakan perintah yang harus dituruti. Oleh karena itu, bentuk kekerasan simbolik dari data diatas disimpulkan sebagai bentuk kekerasan simbolik berdasarkan mekanisme eufemisme atau penghalusan.

\section{PEMBAHASAN}

Bourdieu menciptakan konsep modal, kelas, habitus dan ranah untuk mengungkap dominasi yang diduga selalu ada dalam masyarakat. Bourdieu melihat hubungan atau pemetaan kekuasaan yang terdapat dalam masyarakat berupa bentuk kekuasaan yang berdasar atas kepemilikan dan komposisi modal-modal yang dimiliki. Oleh sebab itu, modal merupakan salah satu aspek penting yang harus dimiliki oleh agen dalam sebuah ranah. Selain modal, habitus merupakan konsep kunci dari pemikiran Bourdieu. Habitus 
mempersatu pemikiran serta tindakan setiap individu dalam suatu ranah. Habitus tidak dapat dipisahkan dari ranah, sebab habitus bekerja dalam ranah.

Setiap arena atau ruang sosial membutuhkan modal dan habitus yang tepat untuk dimainkan di arena itu. Kepemilikan atas modal serta habitus seorang agen akan menentukan kelas dari agen tersebut. Agen yang termasuk dalam kelas dominan dapat melakukan kekerasan simbolik kepada agen lain yang memiliki akumulasi modal lebih sedikit. Kekerasan simbolik yang dilakukan tanpa disadari oleh pihak yang terdominasi, bahkan dianggap sebagai sesuatu yang sudah sewajarnya merupakan kekerasan simbolik. Semua aspek tersebut ditemukan dalam novel Tempurung karya Oka Rusmini. Berdasarkan hasil penelitian yang telah diuraikan sebelumnya. Maka interpretasi yang dapat diperoleh dalam penelitian ini adalah sebagai berikut.

\section{STRUKTURASI KEKUASAAN}

Strukturasi kekuasaan merupakan elemen-elemen penting dalam pembentukan sebuah kekuasaan. Berkuasanya seorang agen harus didukung dengan elemen-elemen tersebut. Dengan adanya strukturasi kekuasaan yang baik, seorang agen akan mampu untuk melakukan kekerasan simbolik terhadap agen lainnya. Elemen-elemen tersebut yakni modal, ranah, kelas dan habitus.

Dalam penelitian ini, modal yang paling bekerja dengan baik yakni modal sosial. Hal ini terlihat dari para agen yang memiliki hubungan dengan para agen lainnya. Dengan hubungan tersebut para agen yang memiliki modal sosial dapat melakukan dominasi atau kekerasan simbolik kepada agen yang memiliki modal lebih sedikit darinya. Agen yang dapat kita jadikan contoh yakni tokoh Glatik dan Saring, dengan adanya hubungan persahabatan diantara mereka berdua Glatik dapat melakukan dominasi kepada Saring untuk menjauhi orang yang dia cintai. Oleh sebab itu, kelas dominan dalam novel Tempurung karya Oka Rusmini ditempati oleh agen yang memiliki modal sosial, berupa hubungan keluarga, pertemanan, dan hubungan kerja sama. Namun, ini bukan berarti bahwa kelas dominan hanya diduduki oleh pemilik modal sosial, pemilik modal lainnya juga ikut masuk di dalamnya. 
Tetapi, agen yang memiliki modal sosial yang paling banyak dalam kelas dominan. Agen pemilik modal sosial tersebut dapat berkuasa karena modal yang mereka miliki dapat bekerja dengan baik dalam sebuah ranah. Terlebih lagi, ranah dalam novel Tempurung karya Oka Rusmini merupakan ranah sosial. Dominasi yang akan timbul di dalamnya tidak akan jauhjauh dari dominasi yang dilakukan dalam keluarga, hubungan persahabatan, hubungan kemasyarakatan dan hubungan lainnya.

Sementara kelas bourjuis kecil ditempati oleh para agen yang memiliki modal lebih banyak dari kelas popular, Agen-agen tersebut bekerja dengan keras dan cerdas untuk menambah akumulasi modal yang mereka miliki. Kerja keras dan kerja cerdas tersebut ditunjukkan melalui cara mereka dalam menghadapi kekerasan simbolik yang mereka terima. Mereka merupakan pemilik modal sosial, namun modal tersebut tidak mereka gunakan untuk mendominasi rekan dalam hubungan sosial yang mereka miliki. Modal sosial tersebut mendatangkan keuntungan bagi kehidupan mereka, misalnya pada tokoh Barla. Barla merupakan seorang lelaki miskin yang dinilai oleh Swandewiyang berasal dari keluarga yang berada. Dengan modal ekonomi yang dimiliki oleh orang tuanya, orang tua Swandewipun melakukan kekerasan simbolik kepadanya agar dapat menerima Swandewi menjadi pacar Barla. Kekerasan simbolikpun dilakukan, dengan mengatakan bahwa mereka akan membayar sekolah Barla, Barlapun menerima kesepakatan tersebut. Melalui kesepakatan tersebut secara tidak disadari, modal sosialpun dimiliki oleh Barla. Meskipun Barla harus menerima Swandewi yang mempunyai rupa yang buruk, tetapi dengan hal tersebut Barla dapat memiliki modal budaya karena orang tua Swandewi yang membiayainya. Hal inilah yang disebut dengan kerja keras dan kerja cerdas.

Selanjutnya kelas popular dalam novel Tempurung karya Oka Rusmini. Kelas popular dalam novel ini memiliki habitus kepatuhan untuk melakukan hal yang mereka yakini. Tidak hanya itu, kepatuhan yang mereka miliki juga dikarenakan rasa hormat dan cinta mereka kepada agen yang memiliki hubungan dengan mereka. Hubungan tersebut berupa hubungan keluarga, pertemanan, kemasyarakat, dan lainnya. Hubungan ini dapat mendatangkan keuntungan dan kerugian bagi mereka. Hal tersebut bergantung pada posisi 
yang mereka hadapi. Setiap orang yang memiliki modal sosial dapat melakukan dominasi kepada rekannya. Namun, penempatan para agen tersebut menjadi kelas popular dilihat dari akumulasi modal dan habitus yang mereka miliki.

Kekuasaan seorang agen juga tidak hanya dipengaruhi oleh modal yang dimilikinya, namun habitus yang terdapat di dalam ranah tersebut. Habitus yang terdapat dalam novel Tempurung karya Oka Rusmini dibagi atas tiga yakni habitus kelas dominan, kelas bourjuis kecil dan kelas popular. Dalam novel Tempurung karya Oka Rusmini, habitus yang dimiliki oleh kelas dominan yakni bahwa mereka dapat melakukan kekerasan simbolik terhadap kelas popular. Hal ini dikarenakan hubungan yang mereka miliki. Misalnya, seorang ibu dapat mengatur kehidupan anaknya karena mereka miliki habitus bahwa apapun yang mereka lakukan adalah yang terbaik untuk anaknya. Hal tersebut merupakan pemikiran yang banyak dikonsumsi oleh masyarakat, khususnya masyarakat yang mengalami kondisi yang sama. Akibatnya menjadi pengetahuan yang bertahan lama dalam ranah tersebut serta menjadi hal dianut oleh kelas tertentu.

Tidak hanya itu, habitus kelas dominan juga turut dipengaruhi oleh sistem kasta dan gelar. Tokoh yang memiliki kasta tertinggi memiliki tingkat kehormatan yang lebih dari yang lainnya. Hal ini membuat kasta yang lebih rendah engan untuk berlaku tidak hormat kepada kasta tertinggi. Akibatnya, mereka dengan mudah dapat melakukan dominasi. Terlebih lagi, jika pemilik kasta tertinggi tersebut memiliki modal lainnya seperti modal ekonomi yang mempuni, praktik dominasi tidak akan dapat terelakkan. Misalnya, tokoh Raja Denpasar dalam novel Tempurung karya Oka Rusmini. Raja tersebut memiliki gelar serta modal yang baik, dengan hal tersebut diapun memiliki kekuasaan untuk mengatur masyarakatnya. Habitus bahwa dialah orang yang paling berkuasa serta tidak seorangpun dapat menentangnya, membuat Raja tersebut semakin melancar melakukan kekerasan simbolik

Sementara itu, habitus yang dimiliki oleh kelas bourjuis kecil yakni bekerja keras dan pandai dalam melihat peluang. Mereka bekerja keras dalam meningkatkan kehidupan mereka agar mereka dapat bertahan didalam ranah dan memiliki kehidupan yang lebih baik dari kelas popular. Meskipun tidak akan menjadi kelas yang dapat melakukan dominasi kepada kelas 
popular, namun setidaknya kelas bourjuis kecil berusaha untuk menjadi kelas yang tidak akan diperlakukan seburuk kelas popular. Berbeda dengan habitus bourjuis kecil, kelas popular justru memiliki habitus patuh. Kepatuhan tersebut digambarkan dalam beberapa dominasi yang terjadi antara ibu dan anak dalam novel Tempurung karya Oka Rusmini. Mereka menganggap bahwa orang tuanya mempunyai hak untuk mengatur kehidupan mereka. Misalnya pada tokoh Songi, saat dia dijual oleh ibunya sendiri untuk menopang kehidupan keluarganya. Dia tidak dapat melakukan apa-apa, dan hanya mengikuti keinginan Ibunya. Hal ini tidak hanya didasari oleh sikap patuh, namun juga mereka menyadari bahwa mereka tidak dapat melakukan apa-apa karena berasal dari keluarga yang kurang mampu. Mereka mempercayai bahwa tidak ada yang dapat mereka lakukan selain mengikuti apa yang menjadi keinginan orang tuanya untuk mendapatkan kehidupan yang lebih baik. Hal tersebut terus menerus dikonsumsi oleh beberapa tokoh yang mengalami kondisi yang sama, secara tidak langsung hal tersebut menjadi sebuah menjadi sebuah habitus yang menyatukan pemikiran beberapa orang bahwa hal tersebut adalah sebuah kewajaran.

Hal ini juga didukung oleh ranah. Ranah dalam novel Tempurung karya Oka Rusmini merupakan ranah sosial. Hal tersebut dapat kita lihat dari kekerasan simbolik yang terjadi. kekerasan simbolik dalam novel Tempurung karya Oka Rusmi terjadi dalam ranah kehidupan sosial masyarakat Bali. Berbagai macam masalah sosial ditunjukan dalam novel tersebut, namun masalah yang paling menonjol yakni kekerasan simbolik yang terjadi pada perempuan baik dalam keluarga, adat maupun dalam hubungan masyarakat. Kekerasan simbolik tidak hanya dilakukan oleh laki-laki kepada perempuan, namun juga dilakukan oleh perempuan ke perempuan lainnya.

\section{KEKERASAN SIMBOLIK}

Dalam novel Tempurung karya Oka Rusmini, kekerasan simbolik digambarkan dalam beberapa tokoh di dalamnya. Tokoh-tokoh tersebut dikelompok menjadi kelas popular. Kebanyakan kelas popular yang mendapatkan kekerasan simbolik dari keluarga, sahabat, rekan kerja, dan hubungan lainnya. Hal ini disebabkan oleh modal sosial yang 
dimiliki rekan mereka. Para kelas popular tidak akan merasakan bahwa mereka telah mendapatkan kekerasan simbol karena kekerasan simbolik merupakan kekerasan yang sifatnya halus serta tidak terlihat sebagai sebuah bentuk dari kekerasan.

Kekerasan ini merupakan kekerasan yang digunakan pada agen-agen sosial tanpa mendapatkan penolakan dari agen-agen tersebut. Hal ini dikarenakan, kekerasan simbolik telah mendapatkan dukungan ataupun telah dianggap sebagai sesuatu yang sah-sah saja. Misalnya tokoh Songi yang dijual Rimpig untuk memenuhi kebutuhan keluarganya. Songi dijadikan pelacur oleh orang tuanya sejak haid pertamanya. Kehidupan keluarga yang sangat serba kekurangan membuatnya harus menjadi tulang punggung keluarganya. Hal tersebut dilakukannya untuk membantu Ibunya agar mendapatkan kehidupan yang lebih baik dari kehidupan mereka dulu. Songi tidak merasakan hal tersebut sebagai sebuah kekerasan, namun sebuah kewajaran karena hal tersebut merupakan hal satu-satunya yang dapat dilakukan untuk Ibunya. Dia merupakan seorang perempuan desa yang miskin, serta tidak memiliki pengetahuan dan keterampilan. Satu-satunya alat yang dapat dijadikannya uang adalah tubuhnya. Pola pikir tersebut merupakan habitus yang mengaturnya untuk berpikir dan bertindak, sehingga dengan habitus tersebut, kekerasan simbolik yang dilakukan ibunya akan dirasakan sebagai sesuatu yang biasa saja atau sudah sewajarnya untuk dilakukan. Hal ini juga sejalan dengan apa yang dikatakan oleh Martono (dalam Melisha, 2017:85) bahwa kekerasan simbolik dianggap sebagai sesuatu yang alamiah dan absah bahkan pihak yang terdominasi tidak akan merasakan hal tersebut sebagai sebuah bentuk kekerasan sehingga dapat berjalan efektif dalam praktik dominasi sosial.

Kekerasan dan kekuasaan simbolik tidak menggunakan secara fisik, melainkan melalui dominasi atas pengakuan dan persetujuan yang terlepas dari kesadaran dan dijalankan menjadi habitus (Bourdieu dalam Wahyuni, 2019:129). Kekerasan tersebut telah diakui dan disetujui secara tidak sadar dan menjadi habitus bagi orang yang mengalami hal tersebut. Sama halnya dengan apa yang dialami oleh Songi, perlakuan Ibunya kepadanya menjadi habitus bahwa orang tua dapat melakukan apapun pada anaknya. Apapun yang diputuskan orang tua merupakan hal yang terbaik untuknya. Hal ini menjadi habitus secara 
umum yang dimiliki oleh beberapa orang. Dengan habitus yang dimiliki oleh Songi, Songipun melakukan hal yang sama kepada anaknya, Sipleg. Sipleg dijual kepada anak pemilik tanah pada umur 16 tahun. Songi berharap anak perempuannya akan mampu memenuhi segala kebutuhannya, sama seperti dirinya dahulu yang dapat memberikan kekayaan kepada Ibunya.

Hal tersebut menggambarkan, bahwa hal yang diterima Songi dari Ibunya menjadi habitus yang melekat pada dirinya. Habitus tersebut membuatnya bertindak sesuai dengan apa yang dia pikirkan, sehingga membuat hal yang sama kepada anak perempuannya. Menurut Wahyuni (2019:129) Kekerasan simbolik terjadi ketika pihak yang didominasi menerima sebuah simbol (konsep, ide, gagasan, kepercayaan, dan prinsip) dalam bentuknya yang distrorsif yang memberikan pengakuan atas sesuatu yang diterima secara distorsif, serta menerapkan kriteria evaluasi kelas dominan untuk menilai diri dan kehidupannya. Di dalam proses kekerasan simbolik, sebenarnya terjadi pemaksaan simbolik yang sangat halus, namun pihak yang didominasi tidak menyadari bahwa dirinya dipaksa. Hal yang demikian disebut dengan common sense. Kekerasan simbolik terlihat seperti sebuah bentuk kerja sama yang menghasilkan keuntungan bagi masing-masing pihak yaitu mendominasi dan yang didominasi.

Dalam penelitian ini, peneliti menyadari bahwa seorang agen dapat mengalami dan melakukan kekerasan simbolik. Hal ini disebabkan oleh habitus yang dimilikinya. Dengan habitus yang dimilikinya, seorang agen akan menjalankan kehidupannya sesuai dengan pola pikirnya tersebut. Namun, untuk melancarkan kekerasan simbolik yang dilakukannya, agen tersebut harus mempunyai modal yang cukup untuk mendominasi dan melakukan kekerasan simbolik kepada agen lainnya. Contohnya, agen Songi. Songi mengalami dan melakukan kekerasan simbolik. Penerimaan pemikiran yang didapatkannya dari Ibunya, membuatnya memiliki habitus yang sama dengan Ibunya. Hal tersebut menjadi habitus untuknya, sehingga jika Songi melihat hal yang sama seperti yang dilakukannya, Songi akan menganggap hal tersebut sebagai sebuah kewajaran. Begitupun agen lainnya yang memiliki habitus yang sama, habitus tersebut menjadi sebuah pemikiran yang mengikat satu dengan yang lainnya. 


\section{SIMPULAN}

Seluruh strukturasi kekuasaan terdapat dalam novel Tempurung karya Oka Rusmini, yakni modal, kelas, habitus dan ranah. Keempat modalpun yakni modal ekonomi, sosial, budaya dan simbolik terdapat dalam novel ini, namun modal yang paling bekerja dengan baik yakni modal sosial. Sementara, para agenpun telah menduduki ketiga kelas yang telah dibagi oleh Bourdieu sesuai dengan modal dan juga habitus yang ada. Para kelas inipun memiliki habitus yang berbeda-beda, hal inilah yang mempengaruhi mereka untuk bertindak dalam ranah tersebut. Sementara ranah dalam novel Tempurung karya Oka Rusmini yakni ranah sosial. Kekerasan simbolikpun terjadi terhadap agen yang memiliki modal paling sedikit. Kekerasan simbolik yang sering terjadi dalam novel Tempurung karya Oka Rusmini yakni kekerasan simbolik yang dilakukan oleh para agen yang memiliki modal sosial. Modal sosial merupakan hubungan timbal balik, sehingga siapapun yang memiliki modal ini dapat melakukan dominasi. Namun, hal ini pun harus didukung oleh habitus yang ada dalam ranah terjadinya kekerasan simbolik.

\section{DAFTAR RUJUKAN}

Arifin,Zaenal.2010. Keutuhan Wacana. Jakarta:Grasindo Bahasa, Sastra dan Pengajarannya. Volume 12 No. 2 Hal 129

Didipu, Herman.2012. Berkenalan Dengan Sastra. Jakarta: Dapur Buku

Harker, Richard. 2009. (Habitus X Modal) + Ranah = Praktik Pengantar Paling Komprehensif kepada http://repository.usd.ac.id/id/eprint/34264 https://doi.org/10.26858/retorika.v12i2.8833 Kesusastraan Indonesia Komisariat USD 2017. Hal 85

Krisdianto, Nanang. 2014. Pierre Bourdieu, Sang Juru Damai. Kanal. Volume 2

Melisha. 2017. Kekerasan Simbolik Orde Baru dalam Novel Pulang Karya Leila \

Moleong, Lexy J. 2014. Metodologi Penelitian. Bandung: PT. Remaja No 2 Hal 202 https://doi.org/10.21070/kanal.v2i2.300 Pemikiran Pierre Bourdieu. Yogyakarta: Jalasutra Rosdakarya

S. Chudori: Perspektif Pierre Bourdieu. Prosiding Himpunan Sarjana-

Wahyuni, Sri dkk. 2019. Kekerasan Simbolik dalam Novel Indonesia. Jurnal 